\title{
A Comparison by the Use of Gel Electrophoresis of Soluble Protein Components and Esterase Enzymes of some Group D Streptococci
}

\author{
BY BARBARA M. LUND \\ Low Temperature Research Station, Downing Street, Cambridge
}

(Received 12 April 1965)

\begin{abstract}
SUMMARY
Soluble cell constituents of strains of Streptococcus faecalis, S. faecium and $S$. durans were studied by electrophoresis in polyacrylamide gels followed by staining the gel to reveal the patterns of separated proteins and esterase enzymes. The patterns of proteins and of esterases found in $S$. faecalis differed from those in $S$. faecium and $S$. durans. Strains of $S$. faecalis differing in serotype and variety showed a very similar series of proteins, some differences in patterns of esterases were found, but similar patterns occurred in strains differing in type and variety. The major protein bands of $S$. faecium and $S$. durans differed in mobility from the major proteins of $\boldsymbol{S}$. faecalis; different strains of $\boldsymbol{S}$. faecium and $\boldsymbol{S}$. durans showed some differences in other protein bands. Esterase activity of $S$. faecium and $S$.durans was weaker than that of $S$. faecalis, and in the case of most strains only faint esterase bands were detected. A strain of $S$. faecium which gave protein and esterase patterns different from those of the remaining strains, differed also in showing motility.
\end{abstract}

\section{INTRODUCTION}

Previous studies of the serology and biochemical reactions of Lancefield group D streptococci have provided a basis for differentiating Streptococcus faecalis and its varieties zymogenes and liquefaciens from $S$. faecium and $S$. durans, and there is evidence of a marked difference between the metabolism of $S$. faecalis and $S$. faecium (Deibel, 1964). To obtain better understanding of the relationships between these organisms, it was thought to be of interest to compare protein macromolecules present in the organisms. Electrophoresis in polyacrylamide gels enables a separation of macromolecules according to their charge and molecular size (Ornstein, 1964; Raymond, 1964). During initial work this technique was used to compare the patterns of separated soluble protein components of cell extracts. The use of starch gel electrophoresis to study multiple forms of esterase enzyme in extracts of Bacillus thuringiensis was reported by Norris (1964) to provide a method of characterizing strains; classification according to 'esterase pattern' showed close correlation with a serological classification. In the experiments reported here the study of esterases has been extended to the group D streptococci. 


\section{METHODS}

Organisms. Table 1 shows the organisms used. Strains of Streptococcus faecalis and its varieties 'liquefaciens' and ' zymogenes' were studied; strains 30/39 and 30/82 were isolated by Dr E. M. Barnes from chicken caeca; the remainder were originally obtained from Dr M. E. Sharpe and were discussed in a recent publication (Sharpe, 1964). The $S$. faecium and $S$. durans strains were described by Barnes (1964) except for B631 which was obtained from Dr M. E. Sharpe. Definitive biochemical tests were confirmed by the methods of Barnes, Ingram \& Ingram (1956).

Table 1. Strains of group D Streptococcus studied

\begin{tabular}{|c|c|c|c|c|c|c|}
\hline \multicolumn{3}{|c|}{ Streptococcus faecalis } & \multicolumn{4}{|c|}{ *Streptococcus faecium and $S$. durans } \\
\hline $\begin{array}{l}\text { Sero- } \\
\text { logical } \\
\text { type }\end{array}$ & Strain & & $\begin{array}{c}\text { Sero- } \\
\text { logical } \\
\text { type }\end{array}$ & Strain & $\begin{array}{l}\text { Sero- } \\
\text { logical } \\
\text { type }\end{array}$ & Strain \\
\hline $\mathbf{1}$ & D76 & Var. liquefaciens & 16 & NH 53 & $\mathbf{3 1}$ & NH 2 \\
\hline 1 & $30 / 39$ & Var. liquefaciens & 18 & $\mathrm{~s} 98$ & 32 & NH 4 \\
\hline 1 & GB 112 & Var. zymogenes & 24 & H 24 & $\mathbf{3 3}$ & P3 \\
\hline $\mathbf{3}$ & $30 / 82$ & - & 25 & $\mathrm{s748}$ & 34 & P7 \\
\hline $\mathbf{3}$ & H 69 D 5 & Var. zymogenes & 26 & CH 1 & 35 & $\mathbf{N} / \mathbf{R} / \mathbf{6 4}$ \\
\hline 4 & GB 122 & Var. liquefaciens & 26 & c3† & $\mathbf{3 6}$ & P1/12 \\
\hline 4 & c1 & Var. zymogenes & 27 & G3 & 37 & $\mathbf{P} 6 / 4$ \\
\hline $\mathbf{5}$ & $\mathbf{N} 83$ & - & 28 & HGH511 & 38 & $\mathbf{P} 17 / 8$ \\
\hline 6 & B 65 & - & 29 & $P 14 / 6$ & 39 & P 16/5: \\
\hline 8 & $1 \mathrm{AS}$ & - & $\mathbf{3 0}$ & GE $4 B$ & 42 & B 631 \\
\hline 40 & $\mathrm{D} 10$ & Var. liquefaciens & - & - & $\begin{array}{l}\text { Not } \\
\text { typed }\end{array}$ & $\mathbf{5 4 2 2}$ \\
\hline 41 & D15 & Var. liquefaciens & - & - & - & 一 \\
\hline
\end{tabular}

Preparation of cell extracts. Cultures were grown for $16-20 \mathrm{hr}$ at $37^{\circ}$ in brain heart infusion broth (Difco Laboratories) with $800 \mathrm{ml}$. medium in 11 . flasks, without agitation or aeration. The bacteria were harvested, washed and finally suspended in water and disrupted by one of two methods.

Method 1. Six g. of a thick suspension $+6 \mathrm{~g}$. ballotini beads (grade 12) per tube

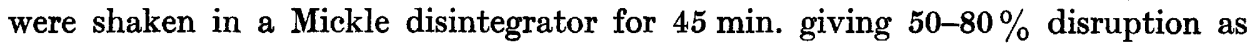
judged by Gram-stained smears. Ballotini and some cell debris was separated by low-speed centrifugation. Method 2. Bacterial suspensions were frozen at $-20^{\circ}$, then disrupted in an X-press (AB Biox. Box 235, Nacka 2, Sweden) previously cooled to between -25 and $-30^{\circ}$; with 3-4 ml. of suspension containing $1 \cdot 5-2 \mathrm{~g}$. wet weight of bacteria, three pressings gave 70-90\% disruption as judged by Gramstained smears. The extracts remained frozen and were sţored at $-20^{\circ}$ until required.

All extracts were clarified by centrifugation at about $60,000 \mathrm{~g}$ for $1 \mathrm{hr}$ and concentrated by vacuum dialysis in collodion shells (Membranfiltergesellschaft Göttingen, W. Germany) against tris citrate gel buffer (see below). The final extracts contained a protein concentration of the order of $40-60 \mathrm{mg} . / \mathrm{ml}$.; this was estimated 
by the method of Lowry, Rosebrough, Farr \& Randall (1957), with bovine albumin (British Drug Houses Ltd., B.D.H.) as standard. These extracts were stored at $-20^{\circ}$ until required.

\section{Preparation of polyacrylamide gel}

Monomer solution. Cyanogum 41 (B.D.H.), $8 \%(w / v)$ in tris citrate buffer (described below).

Catalyst (Raymond \& Wang, 1960). Separate solutions $(a)$ and $(b)$ of the two components of the catalyst system were prepared: $(a) 10 \%(w / v)$ 2-dimethylaminoethylcyanide in water; $(b) 10 \%(w / v)$ ammonium persulphate in water.

Gel mould. This consisted of a rectangular Perspex tray (internal dimensions, length $15.6 \mathrm{~cm}$., width $14.1 \mathrm{~cm}$., depth $0.8 \mathrm{~cm}$.) with a well-fitting lid bearing a removable slot-former of the type described by Smithies (1955). A suitable slotformer carried ten projections, producing insert slots $0.8 \mathrm{~cm}$. wide, $0.7 \mathrm{~cm}$. deep, $0.05 \mathrm{~cm}$. thick, spaced at $0.5 \mathrm{~cm}$. intervals. To prepare the gel $1 \%$ of each of solutions $(a)$ and $(b)$ was added to the monomer solution, the mixture was poured into the Perspex tray and the lid lowered into position. Polymerization occurred within $2 \mathrm{hr}$ at room temperature.

\section{Electrophoresis}

Buffer system. A discontinuous system based on that described by Poulik (1957) was used. The gel buffer (half the concentration used by Poulik) contained tris $38 \mathrm{~mm}$. and citric acid $2.5 \mathrm{mM}$. ( $\mathrm{pH} 8.7$ at $25^{\circ}$ ). The buffer for the electrode vessels contained boric acid $7 \cdot 22 \mathrm{~g} . / 1$. and borax $15 \cdot 75 \mathrm{~g} . / 1 .(0.28 \mathrm{M}$ in terms of borate; $\mathrm{pH} 8.8$ at $25^{\circ}$ ).

Electrophoresis took place in a room maintained at $+1^{\circ}$ to $+5^{\circ}$, at constant voltage $(7-8 \mathrm{~V} . / \mathrm{cm}$. gel), initial current $35-40 \mathrm{~mA}$. decreasing to $10-15 \mathrm{~mA}$. at the end of the experiment. When the marker dye (bromophenol blue) had travelled $8 \mathrm{~cm}$. towards the anode $(6-7 \mathrm{hr})$ the gel was removed, sliced, and stained to demonstrate proteins or esterases.

Protein stain. Naphthalene black 10B (1\%; G. T. Gurr, Ltd.,) in $20 \%$ (v/v) acetic acid in water; the solution was applied for $\mathbf{3 0}$ min. and background stain then removed by successive rinses with $7 \cdot 5 \%$ acetic acid in water.

Esterase stain (Lawrence, Melnick \& Weimer, 1960). The gel slice was flooded with a freshly prepared solution containing tris maleate buffer $(0 \cdot 1 \mathrm{M} ; \mathrm{pH} \mathrm{6} \cdot 4)$ $50 \mathrm{ml}$.; a solution of $\alpha$-naphthyl acetate (1\%) in $50 \%(\mathrm{v} / \mathrm{v})$ acetone in water, $2 \mathrm{ml}$., Fast blue BB salt (Sigma Chemical Co.), $50 \mathrm{mg}$. Esterase activity, was shown by the appearance of dark red bands which developed in $1 \mathrm{hr}$ at room temperature.

Photography. Stained gels were photographed by transmitted light on Pan F film (Ilford Ltd.) and (for protein patterns) with a yellow filter (Ilford Ltd., filter no. 110).

\section{RESULTS}

\section{Effect of method of disintegration}

Extracts prepared by the two methods of disintegration of the bacteria gave similar patterns of proteins and esterase bands. It is probable that for subsequent study of more labile enzymes the use of the $\mathrm{X}$-press, in which the extract remains frozen, will be more satisfactory than the use of the Mickle shaker, in which it is difficult to prevent an increase of temperature during disintegration. 


\section{Protein bands}

All of the strains of Streptococcus faecalis and its varieties liquefaciens and zymogenes gave a similar pattern of protein bands ('protein pattern'), with major protein components of the different extracts showing similar mobility. Typical results are shown in Pl. 1, fig. 1. Patterns shown by strains of $S$. faecium and $S$. durans are illustrated in Pl. 2, fig. 3. Major protein components of the different extracts showed similar mobility; with the less-marked bands there were some differences between different strains of $S$. faecium and $S$. durans, but of 20 strains initially studied (representing 19 known serotypes) all but one gave patterns resembling those of Pl. 2, fig. 3, in position of the major bands. The exception was strain P14/6, serotype 29.

The protein patterns of strains of Streptococcus faecalis, $S$. faecium and $S$. durans are compared in $\mathrm{Pl}$. 2, fig. 4. When protein bands at a distance of 3-5 cm. from the inserts were examined a difference was apparent in the position of the most marked bands in extracts of $S$. faecalis (a), typical $S$. faecium $(\mathrm{b}, \mathrm{d})$ and a $\beta$-haemolytic $S$. durans (c). Plate 2, fig. 4, also shows the protein pattern given by $S$. faecium strain $P 14 / 6$, which differed quite markedly from those of the remaining strains of $S$. faecium, $S$. durans and of $S$. faecalis.

\section{Esterase bands}

Streptococcus faecalis strains possessed active esterases, and well-defined bands were detected after electrophoresis; typical results are shown in PI. 1, fig. 2. Esterase 1 produced a wide zone of marked enzyme activity, except in the case of strain $\mathrm{Cl}$ (fig. 2, extract $\mathrm{f}$ ); in 1 strain (N 83; fig. 2, extract $g$ ) out of 12 studied this band was replaced by a similar one with slightly greater mobility (esterase 1a). Esterase 2 was detected in 9 of the 12 strains but was either very weak or not detected in the other 3 strains. Esterase 3 was a faint band shown by 3 strains in Pl. 1, fig. 2 (extracts $g, h, j$ ). Other very faint bands were sometimes detected and can be seen in the photograph. S. faecium strains generally showed weak rather ill-defined esterase bands; $S$. durans strain c3 showed distinct bands but lacked the strong esterase-1 band generally characteristic of $S$. faecalis. In view of the faintness of the esterase bands of $S$. faecium these have not been described in detail; a striking difference was shown by strain $P 14 / 6$ which, in contrast with the remaining strains of $S$. faecium, gave strong bands of esterase activity.

Esterase patterns of Streptococcus faecalis strain 30/82, S. faecium P3, S. durans $\mathrm{C3}$ and $S$. faecium 5422 and P14/6 are illustrated in Pl. 2, fig. 5.

\section{Streptococcus faecium strain $P 14 / 6$, serotype 29}

This strain, distinguished by its unusual pattern of proteins and esterases, differed from all the other strains in showing motility, readily observed in microscopic examination of 8-24 $\mathrm{hr}$ broth cultures at $30^{\circ}$, and demonstrated by diffuse growth in brain heat infusion broth containing $0 \cdot 25 \%$ agar (Davis). This strain also produced variants which gave red colonies on the thallous acetate + tetrazolium agar medium of Barnes (1956). These characters were also noted for this strain by Sharpe \& Fewins (1960) and by Barnes (1964). 


\section{DISCUSSION}

\section{Protein patterns}

In this study of soluble proteins, strains of Streptococcus faecalis and its varieties 'zymogenes' and 'liquefaciens', of several serotypes, showed very similar protein patterns, which contrasted with the pattern shown by the strain of $S$. faecium. The patterns for $S$. durans strains (C3, $\beta$-haemolytic; P16/5 and P17/8, $\alpha$-haemolytic) appear more like that of $S$. faecium than that of $S$. faecalis. These results substantiate the previous differentiation between $S$. faecalis and $S$. faecium/S. durans, made on the basis of serology and biochemical reactions. The different protein patterns of $S$. faecalis and $S$. faecium/S. durans may be due to differences between the metabolism of these organisms, and hence a quantitative and qualitative difference between the major enzymes present; an objective of future experiments will be to identify some of the major bands in order to understand the significance of this difference.

\section{Esterase patterns}

A probable difference between the metabolism of Streptococcus faecalis and that of $S$. faecium/S. durans is illustrated by the difference in esterase activity of these organisms. The ability to hydrolyse $\alpha$-naphthyl acetate is shown by various types of esterase; the physiological significance of the enzymes observed here requires further study.

Plate 1, fig. 2, shows that similar esterase patterns were given by Streptococcus faecalis strains of different serotype (e.g. extracts $c, d, e, k$ ) and by varieties faecalis (d), liquefaciens (a, b, e, k) and zymogenes (c). In some cases a difference in esterase pattern was found between two strains of the same serotype, e.g. GB 122, var. liquefaciens (e) and $c 1$, var. zymogenes (f). Only one strain of serotype 5 (N83) was examined; it remains to be seen whether band $1 \mathrm{a}$ is a general feature of strains of this serotype.

In the case of Bacillus thuringiensis (Norris, 1964) esterase patterns were found to be type-specific and to provide a means of identifying new isolates. The major esterases of several of the $\boldsymbol{B}$. thuringiensis serotypes showed similar mobilities, and a comparison of other fainter bands was necessary to make a distinction between the serotypes. It is possible that such faint esterase bands are better detected on starch gels, as used by Norris (1964), than on polyacrylamide gels. The latter technique was used in the present work with streptococci because it enabled a much better separation of components in the extracts prepared by Mickle disintegration at the outset of this work, and the transparency of the gel readily enabled a more sensitive detection of protein bands than did the use of starch gels.

Streptococcus faecium strain $P 14 / 6$. The comparison of protein and esterase pattern distinguished this motile strain from the remaining non-motile strains of $S$. faecium. Preliminary experiments have shown that two other motile strains of this serotype (isolated from different sources) gave protein and esterase patterns similar but not identical to those of strain P14/6; a further study of the significance of these results is in progress.

Streptococcus faecium strain 5422 was labelled in our collection as belonging to serotype 29 (of which P14/6 is the type strain) and was non-motile. The finding that 
protein and esterase patterns of strain 5422 differed from those of $P 14 / 6$, caused a check to be made of the history of strain 5422. It was found that a mistake had occurred in the correlation of typing systems : $\mathbf{5 4 2 2}$ did not belong to the same serotype as $\mathrm{P} 14 / 6$; this was confirmed experimentally.

The author is grateful to Dr E. M. Barnes for access to her collection of group D streptococci and for helpful discussions, to Dr J. R. Norris for advice regarding the preparation of polyacrylamide gels, and to Miss E. Higgins for technical assistance.

\section{REFERENCES}

Barnes, E. M. (1956). Methods for the isolation of faecal streptococci (Lancefield group D) from bacon factories. J. appl. Bact. 19, 193.

Barnes, E. M. (1964). Distribution and properties of serological types of Streptococcus faecium, Streptococcus durans and related strains. J. appl. Bact. 27, 461.

Barnes, E. M., Ingram, M. \& Ingram, G. C. (1956). The distribution and significance of different species of faecal streptococci in bacon factories. J. appl. Bact. 19, 204.

Derbel, R. H. (1964). The group D streptococci. Bact. Rev. 28, 330.

Lawrence, S. H., Melničk, P. J. \& Weimer, H. E. (1960). A comparison of serum proteins and enzymes by starch gel electrophoresis. Proc. Soc. exp. Biol. Med. 105, 572.

Lowry, O. H., Rosebrough, N. J., Fark, A. L. \& Randall, R. J. (1951). Protein measurement with the Folin phenol reagent. J. biol. Chem. 193, 265.

Norris, J. R. (1964). The classification of Bacillus thuringiensis. J. appl. Bact. $27,439$.

Ornstein, L. (1964). Dise electrophoresis. 1. Background and theory. Ann. N.Y. Acad. Sci. 121, 321.

Pounr, M. D. (1957). Starch gel electrophoresis in a discontinuous system of buffers. Nature, Lond. 180, 1477.

RaYmond, S. (1964). Acrylamide gel electrophoresis. Ann. N.Y. Acad. Sci. 121, 350.

Raymond, S. \& Wang, Y. (1960). Preparation and properties of acrylamide gel for use in electrophoresis. Analyt. Biochem. 1, 391.

Sharpe, M. E. (1964). Serological types of Streptococcus faecalis and its varieties and their cell wall type antigen. J. gen. Microbiol. 36, 151.

Sharpe, M. E., \& Fewins, B. G. (1960). Serological typing of strains of Streptococcus faecium and unclassified group D streptococci isolated from canned hams and pig intestines. J. gen. Microbiol. 23, 621.

Smrthres, 0. (1955). An improved procedure for starch gel electrophoresis: further variations in the serum proteins of normal individuals. Biochem. J. 71, 585.

\section{EXPLANATION OF PLATES}

\section{Plate 1}

Study of soluble components of extracts of strains of Streptococcus faecalis by electrophoresis on polyacrylamide gel. The two different gels shown here contained the same series of extracts.

Fig. 1. Gel stained with naphthalene black $10 \mathrm{~B}$ to detect protein bands.

Fig. 2. Gel incubated in the presence of $\alpha$-naphthyl acetate and Fast blue BB to detect esterase. enzymes.

$(a)=$ strain $\mathbf{D 7 6}$, type 1 (var. liquefaciens); $(b)=$ strain 30/39, type 1 (var. liquefaciens); $(c)=$ strain GB 112, type 1 (var. zymogenes); $(d)=$ strain 30/82, type 3; $(e)=$ strain $\mathbf{G B} 122$, type 4 (var. liquefaciens); $(f)=\mathrm{c} 1$, type 4 (var. zymogenes); $(g)=$ strain $\mathrm{N} 83$, type $5 ;(h)=$ strain $\mathrm{B} 65$, type $6 ;(j)=$ strain $\mathrm{D} 10$, type 40 (var. liquefaciens); $(k)=$ strain $\mathrm{D} 15$, type 41 (var. liquefaciens). 


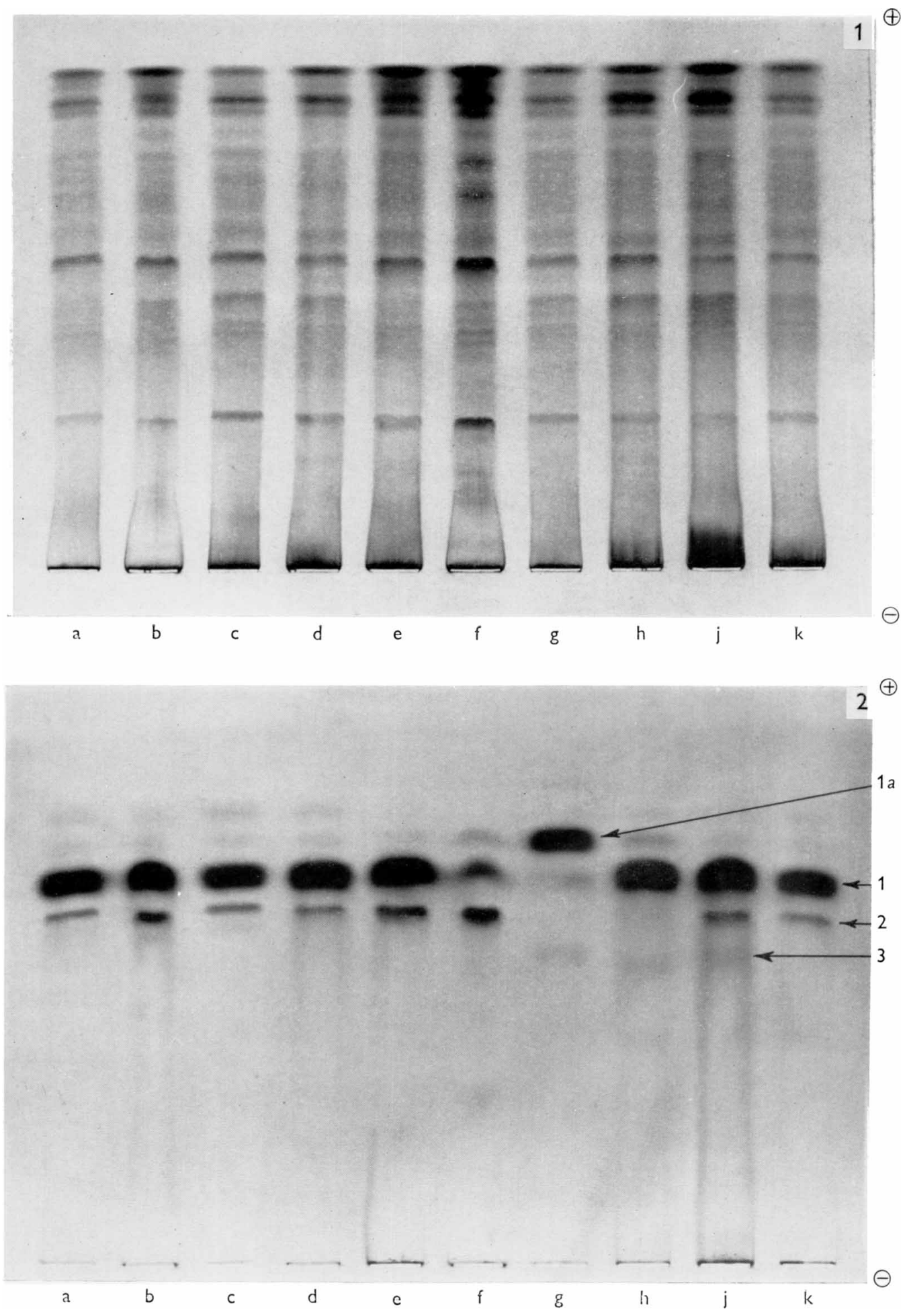

B. M. LUND

(Facing p. 418) 
Journal of General Microbiology, Vol. 40, No. 3

Plate 2
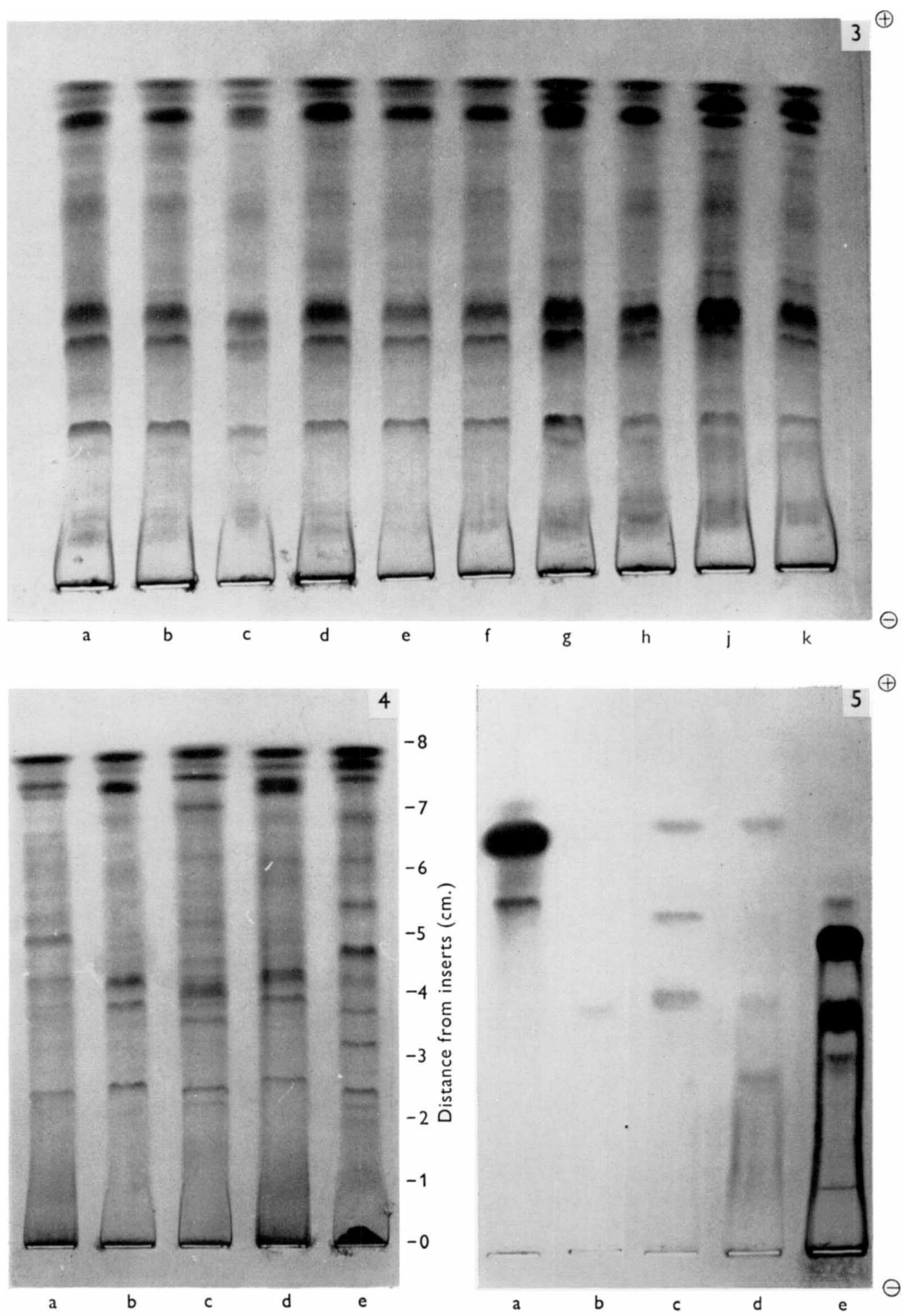

B. M. LUND 


\section{Plate 2}

Studies of soluble components of cell extracts by electrophoresis on polyacrylamide gel.

Fig. 3. Extracts of Streptococcus faecium and $S$. durans; gel stained with naphthalene black 10B to detect protein bands.

$(a)=$ strain s 98, type 18, S. faecium; $(b)=$ strain н 24, type 24, S. faecium; $(c)=$ strain нGн 511, type 28, S. faecium; $(d)=$ strain GE 4 B, type 30, S. faecium; $(e)=$ strain P3, type 33, S. faecium; $(f)=$ strain P7, type 34, $S$. faecium; $(g)=$ strain N/R/64, type 35, S. faecium; $(h)=$ strain P1/12, type 36, $S$. faecium; $(j)=$ strain $\mathbf{P 1 6} / 5$, type 39, $S$. durans; $(k)=$ strain P17/8, type 38, $S$. durans.

Figs. 4, 5. Comparison of extracts of strains of $S$. faecalis, $S$. faecium, and $S$. durans. The two different gels contained the same series of extracts.

Fig. 4. Gel stained to detect protein bands.

Fig. 5. Gel incubated with $\alpha$-naphthyl acetate and Fast Blue BB to detect esterase enzymes.

$(a)=S$. faecalis, 30/82; $(b)=S$. faecium, P3, type 33; $(c)=S$. durans, c3, type 26 ( $\beta$-haemolytic); $(d)=S$. faecium, 5422, not typed; $(e)=S$. faecium, P 14/6, type 29. 